\title{
PECULIARITIES OF STRESSORS EXPERIENCED BY PHYSICAL EDUCATION TEACHERS AT WORK
}

\author{
Andrius Stočkus, Eugenija Adaškevičienė \\ Klaipèda University, Klaipéda, Lithuania
}

\begin{abstract}
Research background and hypothesis. The article focuses on assessment of stressors experienced by physical education teachers in their work. As surveyed researchers notice, stress at work can cause a depressive mood, anxiety, tiredness and, eventually, serious illnesses. Under constant and overwhelming stress, a real threat of formation of the burnout syndrome appears. This is a condition of emotional, psychic and physical exhaustion formed under long-lasting unsolved stresses arising in work-related situations. Stress also significantly influences work efficiency, creativity and competitiveness. It is very important to notice that the change of personality features in a teacher experiencing stress or, even worth, the burnout syndrome, leave traces on the other person. Thus, it is necessary to go deeper into this scientific problem: what stressors are characteristic to the work of physical education teachers, what are the correlations with the socio-demographic variables

The aim of the research was to assess work-related stressors of physical education teachers and their relation with socio-demographic variables. Teachers of physical education $(n=118$ in comprehensive schools took part in the research.

Research methods applied in the research: the data was collected using questionnaires on work-related stressors and socio-demographic information; the data obtained was processed by applying the parameter statistics, MannWhitney $(\mathrm{U})$ criterion was employed as well.

Research results. The research showed that teachers of physical education listed the following as the most important sources of stress at work: abundance of various documents and other "papers", reforms of the educational system and high responsibility for pupils. Unfavourable work conditions, psychological climate at school, work with groups of pupils of different genders, problems with pupils' parents almost did not cause stress to teachers of physical education. Younger teachers or those less experienced in pedagogical work felt more stress about high numbers of pupils in a sports hall than their senior or more experienced colleagues did. Senior and more experienced teachers of physical education emphasised that they underwent the following more intensive work-related stressors: high responsibility for others, abundance of various documents and other "papers", underestimation of physical education teachers' work. Men were unsatisfied with low salaries, and women indicated that the attitude of teachers in other subjects towards physical education caused dissatisfaction with work. Male teachers' low salaries and female teachers' perceived unappreciated attitude towards physical education caused stress to them. Teachers working in cities, towns assessed pupils' disrespect and high numbers of pupils in forms as a bigger stressor than teachers of physical education in districts. Physical education teachers working in gymnasiums assessed competition inside an educational institution as a stronger stressor rather than educators working in the main or secondary schools.

Discussion and conclusions. In the aspect of work-related stressors of physical education teachers, teachers list abundance of various documents and reforms of the educational system as main sources of stress at work. Negative attitude of other colleagues towards teachers of physical education as well as competition among staff at school, and, on the other hand, negative attitude of pupils towards physical education have been revealed. Analysis of correlations between work-related stressors and socio-demographic variables suggests that younger pedagogues experience higher stress caused by reforms of the educational system and a high amount of pupils in a sport hall during lessons in comparison to their senior colleagues; while senior teachers of physical education emphasise responsibility as a higher work-related stress.
\end{abstract}

Keywords: physical education, teachers' stress, burn out. 


\section{INTRODUCTION}

$\mathrm{P}$ resently, the concept of stress is very popular throughout the world and is often used in the life fields related to work and profession. Problems at work are more often related to complaints about health rather than about financial or family problems*.

The issue of stress at work does not leave aside the occupations that are related to education. Many authors (Bulotaite, Lepeškiene, 2006; Chaplain, 2008; Tonder, Williams, 2009; Brudnik, 2009; Clausen, Petruka, 2009; Ozan, 2009; Bubelienè, 2010) note that the pedagogue's profession belongs to the category of professions attributed with constant tension, increased anxiety, negative emotions, stress which in the Dictionary of Psychology (Psichologijos žodynas, 1993) is defined as a human's condition arising from various extreme impacts, i. e. stressors. A stressor is an unfavourable factor causing anxiety, negative emotions, i. e. stress. Dealing with problems of stress in professional activities, definitions dedicated to the labour context appear. Workrelated stressors are events of the work-related environment and outside it perceived by employers as making the impact on satisfaction with work, productivity and psychic health (Hammer et al., 2004). The most strongly and painfully perceived stressors for teachers are those occurring in the context of the macro-level (Bubeliene, 2010): continuous reforms of the educational system, decrease in the profession's prestige, too high work load, low salary. The following are the most often listed problems causing stress and other negative feelings to pedagogues: conflicts of teachers' roles, uncertainty about the future, bad relationships with colleagues, schoolchildren as well as disobedient pupils. L. Bulotaitè, V. Lepeškienè (2006) divide teachers' stressors into six categories: changes in the educational system and social plane; conflicts of roles and confusion of roles; bad physical and social conditions for work; problematic pupils; poor professional relationships and collaboration with colleagues; problematic teachers.

Stress at work can cause a depressive mood, anxiety, tiredness and, eventually, serious illnesses. Under constant and overwhelming stress,

\footnotetext{
* The European Union Agency of Safety and Health at Work (EU-OSHA) 3 June 2010. "2007-2012 Revision of the Interim Period of EC Strategy on Health and Safety at Work" (conference).
}

a real threat of formation of the burnout syndrome appears (Maslach et al., 2001; Dirgèlienè, Večkienè, 2009). This is a condition of emotional, psychic and physical exhaustion formed under long-lasting unsolved stresses arising in workrelated situations (Maslach et al., 2001). Stress also significantly influences work efficiency, creativity and competitiveness (Bubeliene, 2010). It is very important to note that the change of personality features in a teacher experiencing stress or, even worth, the burnout syndrome, leave traces on the other person (Мерзлякова, 2009).

When talking about teacher's profession and stress, it is necessary to mention that significance of teachers of various specialities in the educational process is assessed differently. L. Kardeliene (2008) states that those taught subjects which are not being examined are lower assessed in the educational system because they are peripheral with regard to school's basic instrumental function. Because of that, the status of teachers who are specialists of non-academic subjects decreases. Research data (Silverman, Subramaniam, 1999; Panczyk, 2005) shows that pupils assess teachers of physical education much lower than educators delivering other subjects.

There are many countries in the world where teachers of physical education are assessed lower than teachers of other specialities, and physical education as a subject is neglected by school administration, teachers of other subjects, pupils, their parents (Hardman, 2008; Krawanski, 2009). N. Fejgin et al. (1995) suppose that specificity of physical education teachers' work is unique and completely differs from performance of other participants of the educational process. First of all, it is related with the learning facilities, quantity and quality of sports equipment and inventory, the environment where lessons of physical education are held (sports hall, stadium, playground etc.). Also, the educational process faces issues of pupils' safety and order during lessons because to control actively moving pupils is more difficult than those calmly sitting in a classroom. In Lithuania there has not been much research of this kind carried out so far (Bagdonas, 2004; Bulotaitè, Lepeškienè 2006; Bubelienè, 2007; Dirgèlienè, Večkienè, 2009; Bubelienè, 2010), and no works dealing with the issues of physical education teachers' stress have been found. Thus, it is necessary to go deeper 
into this scientific problem: what stressors are characteristic of the work of physical education teachers, what are their correlations with the sociodemographic variables?

Stressors undergone by physical education teachers in their work are the research object.

The research aimed to investigate workrelated stressors of physical education teachers and to estimate their correlations with sociodemographic variables.

\section{RESEARCH METHODS}

The sample. Teachers of physical education $(n=118)$ from various cities, towns and districts (Kaunas, Šiauliai, Šiauliai District, Tauragè, Pakruojis) of Lithuania took part in the research. Recorded socio-demographic variables are presented in Table 1.

Research methods and organisation.

1. Questionnaire on work-related stresses was designed grounding on the recent data of research on teachers' work-related stress carried out by a number of authors (Bagdonas, 2004; Bulotaitè, Lepeškienè 2006; Dirgèlienè, Večkienė, 2009; Bubelienė, 2010). Physical education teachers were presented with 29 aspects of their work and they were asked to assess each of them on a scale from 1 (completely stress-free) to 4 (constantly causes stress). The internal consistency Cronbach's alpha was 0.908.

2. Questionnaire on socio-demographic data. The following socio-demographic variables were recorded: teacher's gender; age; work experience at school; work load; pedagogical qualification; geographical location of a school; school type.

To process the research data, methods of statistical analysis were employed. Quantitative research data analysis was carried out by a software package SPSS 16.0 (Statistical Package for Social Sciences). To assess statistical reliability of differences between groups of the research sample, Mann-Whitney (U) criterion was used.

\section{RESEARCH RESULTS}

Work-related stressors of physical education teachers. Having assessed the aspects of physical education teachers' work that cause stress, all factors were rated according to the means of answers. The research results are presented in Table 2.

The research results displayed in Table 2 suggest that the following were the major sources of stress, as teachers listed them: "Abundance of various documents and other "papers" and "Reforms of the educational system". The latter aspects of work are not closely related to direct work of a physical education teacher or pedagogical activities. The aspect of teacher's work, "High responsibility for others", is directly related to the specificity of physical education teacher's work. The data of our research also showed that physical education teachers exactly indicated "Negative attitude of colleagues (other teachers) towards physical education" as the factor causing stress at work. Moreover, teachers of physical education underwent negative impact of "Competition at school" as well.
Table 1. Socio-demographic data of the research participants

Note: $\mathrm{M} / \mathrm{SD}$ is for mean/standard deviation.

\begin{tabular}{|c|c|c|c|c|}
\hline \multirow{2}{*}{ Age } & Under 35 years & \multicolumn{2}{|c|}{ Over 35 years } & $\mathrm{M} / \mathrm{SD}$ \\
\hline & $27.1 \%$ & \multicolumn{2}{|c|}{$72.9 \%$} & $44.7 \pm 8.6$ \\
\hline \multirow{2}{*}{ Gender } & \multicolumn{2}{|l|}{ Male } & \multicolumn{2}{|c|}{ Female } \\
\hline & \multicolumn{2}{|l|}{$58 \%$} & \multicolumn{2}{|c|}{$42 \%$} \\
\hline \multirow{2}{*}{ Work experience } & Under 10 years & \multicolumn{2}{|c|}{ Over 10 years } & $\mathrm{M} / \mathrm{SD}$ \\
\hline & $26.3 \%$ & \multicolumn{2}{|c|}{$73.7 \%$} & $20.7 \pm 9.9$ \\
\hline \multirow{2}{*}{ Work load } & \multirow{2}{*}{\multicolumn{2}{|c|}{ From 8 to 28 hrs per week }} & \multicolumn{2}{|c|}{$\mathrm{M} / \mathrm{SD}$} \\
\hline & & & \multicolumn{2}{|c|}{$20.5 \pm 5.4$} \\
\hline \multirow{2}{*}{$\begin{array}{c}\text { Geographical location of } \\
\text { a school }\end{array}$} & \multicolumn{2}{|c|}{ City, town school } & \multicolumn{2}{|c|}{ District school } \\
\hline & \multicolumn{2}{|l|}{$65.3 \%$} & \multicolumn{2}{|c|}{$34.7 \%$} \\
\hline \multirow[t]{2}{*}{ Pedagogical qualification } & Teacher & \multicolumn{2}{|c|}{ Senior teacher } & $\begin{array}{c}\text { Teacher } \\
\text { methodologist }\end{array}$ \\
\hline & $7.6 \%$ & & $.4 \%$ & $50 \%$ \\
\hline \multirow{2}{*}{ Type of a school } & Main school & Secon & ry school & Gymnasium \\
\hline & $29 \%$ & \multicolumn{2}{|c|}{$22.9 \%$} & $38.1 \%$ \\
\hline
\end{tabular}


Table 2. Physical education teachers' work aspects causing stress

\begin{tabular}{|c|c|c|}
\hline No. & Physical education teachers' work aspects causing stress & Mean assessment \\
\hline 1. & Abundance of various documents and other "papers" & 2.93 \\
\hline 2. & Reforms of the educational system & 2.86 \\
\hline 3. & High responsibility for others & 2.80 \\
\hline 4. & Low, insufficient salary & 2.78 \\
\hline 5. & Societal attitude towards physical education teacher's work & 2.72 \\
\hline 6. & Negative attitude of colleagues (teachers of other subjects) towards physical education & 2.66 \\
\hline 7. & Lack of pupils' motivation for physical education & 2.66 \\
\hline 8. & Underestimation of physical education teacher's work & 2.66 \\
\hline 9. & Competition at school & 2.57 \\
\hline 10. & Disregard of the physical education subject by pupils' parents & 2.54 \\
\hline 11. & Disrespect from pupils & 2.40 \\
\hline 12. & High numbers of pupils in classes & 2.24 \\
\hline 13. & Disregard of the physical education subject by pupils & 2.19 \\
\hline 14. & Deadlines for performance of tasks, hurry & 2.14 \\
\hline 15. & High amount of pupils in a sport hall during lessons & 2.11 \\
\hline 16. & High requirements for a physical education teacher & 2.05 \\
\hline 17. & Many roles attributed to a physical education teacher (to teach, to educate, to take care) & 1.98 \\
\hline 18. & Limitations for career development & 1.95 \\
\hline 19. & Lack of information at school & 1.92 \\
\hline 20. & Negative attitudes of school administration towards physical education & 1.87 \\
\hline 21. & Noise at school, in a sport hall & 1.85 \\
\hline 22. & Negative attitude of pupils towards physical education & 1.82 \\
\hline 23. & Requirements for development of qualification & 1.81 \\
\hline 24. & Complex requirements for curricula & 1.76 \\
\hline 25. & Constant checking, commissions & 1.72 \\
\hline 26. & Unfavourable work conditions at school & 1.66 \\
\hline 27. & Work with groups of pupils of different genders & 1.57 \\
\hline 28. & Psychological climate at school & 1.53 \\
\hline 29. & Problems with pupils' parents & 1.49 \\
\hline
\end{tabular}

Specialists of physical education singled out the following important and intensive work-related stressors: low salary, unfavourable attitude of the society towards physical education teacher's work, lack of pupils' motivation for sports, underestimation of physical education teacher's work by pupils' parents. It is interesting to note that such work aspects as "Unfavourable conditions for work at school", "Negative attitude of pupils towards physical education" were quite lowly assessed by the respondents.

Correlations between work-related stressors and socio-demographic variables. Having analysed research results, it was found out that opinions of the respondents in the aspect of age differed regarding the following work-related stressors: "Reforms of the educational system", "High responsibility for others", "High numbers of pupils in a sport hall during lessons". Table 3 shows that younger pedagogues, those under the age of 35 , experienced higher stress because of reforms of the educational system $(\mathrm{p}<0.0001)$ and high numbers of pupils in a sport hall during lessons $(\mathrm{p}<0.05)$ than their senior colleagues (at the age over 35). Senior teachers of physical education emphasised that the responsibility for others was a higher workrelated stress $(p<0.05)$ to them.

Assessment of physical education teachers' work-related stressors in the aspect of gender (Table 4) revealed that male teachers experienced higher stress because of low salary than women $(\mathrm{p}<0.01)$. E. Zak and T. Horowitz (1985) (cited 
from Fejgin et al., 1995) stated that the society held the dominating opinion that man's income in the family took "the first" place in a family budget, and woman's income was identified with additional expenses. Meanwhile, female teachers considered a negative attitude of colleagues (other teachers) towards physical education as a greater stressor compared with their male counterparts $(\mathrm{p}<0.01)$.

Table 5 suggests that pedagogues working for more than 10 years consider the abundance of various documents and other "papers" a higher stressor than those teachers working up to 10 years $(\mathrm{p}<0.05)$. Especially significant difference $(\mathrm{p}<$ $0.001)$ was observed in respondents' answers on underestimation of physical education teachers' work. Teachers working for a longer time indicated this aspect as the one causing more stress than their colleagues working for a shorter period than 10 years. The investigation of intensity of work- related stressors in the aspect of work experience points out that physical education teachers working up to 10 years feel more stress $(\mathrm{p}<0.01)$ because of higher numbers of pupils in a sport hall during lessons. Less experienced young teachers are unable to effectively work with big groups of pupils during the lessons.

Research results revealed that physical education teachers working in the city schools and district schools assessed disrespect from pupils and high numbers of pupils in different ways. Pedagogues working in cities, towns, assessed disrespect from pupils $(\mathrm{p}<0.01)$ and high numbers of pupils in classes $(\mathrm{p}<0.05)$ as a more intensive stressor than physical education specialists working in districts.

It was also found out that the respondents working in gymnasiums assessed competition at school as a stronger stressor that those working in the main or secondary schools $(\mathrm{p}<0.001)$.

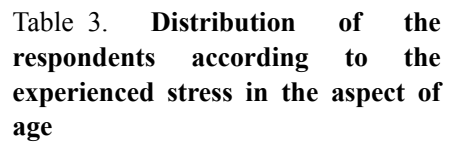

\begin{tabular}{|c|c|c|c|}
\hline The research sample & Mann-Whitney U & $\mathbf{p}$ & $\begin{array}{l}\text { Mean } \\
\text { range }\end{array}$ \\
\hline \multicolumn{4}{|c|}{ Reforms of the educational system } \\
\hline Teachers under 35 years of age, $n=32$ & \multirow{2}{*}{726.000} & \multirow{2}{*}{0.0001} & 79.81 \\
\hline Teachers over 35 years of age , $n=86$ & & & 51.94 \\
\hline \multicolumn{4}{|c|}{ High responsibility for others } \\
\hline Teachers under 35 years of age, $n=32$ & \multirow{2}{*}{1042.500} & \multirow{2}{*}{0.05} & 49.08 \\
\hline Teachers over 35 years of age , $n=86$ & & & 63.38 \\
\hline \multicolumn{4}{|c|}{ High numbers of pupils in a sport hall during lessons } \\
\hline Teachers under 35 years of age, $n=32$ & \multirow{2}{*}{1016.000} & \multirow{2}{*}{0.05} & 70.75 \\
\hline Teachers over 35 years of age, $n=86$ & & & 55.31 \\
\hline
\end{tabular}

Table 4. Distribution of the respondents according to the experienced stress in the aspect of gender

\begin{tabular}{|c|c|c|c|}
\hline The research sample & Mann-Whitney U & $\mathbf{p}$ & $\begin{array}{l}\text { Mean } \\
\text { range }\end{array}$ \\
\hline \multicolumn{4}{|c|}{ Low, insufficient salary } \\
\hline Male, $\mathrm{n}=68$ & \multirow{2}{*}{1180.000} & \multirow{2}{*}{0.01} & 67.14 \\
\hline Female, $\mathrm{n}=50$ & & & 49.11 \\
\hline \multicolumn{4}{|c|}{ Negative attitude of colleagues (other teachers) towards physical education } \\
\hline Male, $\mathrm{n}=68$ & \multirow{2}{*}{1202.000} & \multirow{2}{*}{0.01} & 52.18 \\
\hline Female, $\mathrm{n}=50$ & & & 69.46 \\
\hline
\end{tabular}




\begin{tabular}{|c|c|c|c|}
\hline The research sample & Mann-Whitney U & $\mathbf{p}$ & $\begin{array}{l}\text { Mean } \\
\text { range }\end{array}$ \\
\hline \multicolumn{4}{|c|}{ Abundance of documents and other "papers" } \\
\hline Teachers working for under 10 years, $n=31$ & \multirow{2}{*}{1002.500} & \multirow{2}{*}{0.05} & 48.34 \\
\hline Teachers working for over 10 years, $\mathrm{n}=87$ & & & 63.48 \\
\hline \multicolumn{4}{|c|}{ Underestimation of physical education teacher's work } \\
\hline Teachers working for under 10 years, $n=31$ & \multirow{2}{*}{864.000} & \multirow{2}{*}{0.001} & 43.87 \\
\hline Teachers working for over 10 years, $\mathrm{n}=87$ & & & 65.07 \\
\hline \multicolumn{4}{|c|}{ High numbers of pupils in a sport hall during lessons } \\
\hline Teachers working for under 10 years, $n=31$ & \multirow{2}{*}{970.500} & \multirow{2}{*}{0.01} & 71.69 \\
\hline Teachers working for over 10 years, $\mathrm{n}=87$ & & & 55.16 \\
\hline
\end{tabular}

Table 5. Distribution of the respondents according to the undergone stress in the aspect of work experience

\section{DISCUSSION}

Dealing with the aspect of work-related stressors of physical education teachers we found out that teachers listed abundance of various documents and reforms of the educational system as main sources of stress at work. Similar data has been obtained in other research works by L. Bulotaite, V. Lepeškienè (2006), C. L. Tonder, C. Williams (2009) involving teachers delivering not only physical education, but also other subjects. However, underlining the specificity of physical education teacher's work, scientists K. Hardman (2008), A. Krawansky (2009), M. Brudnik (2009) point out that physical education teachers must take care of safety of pupils' physical health during lessons. Moreover, our research results revealing negative attitude of other colleagues towards teachers of physical education as well as competition among staff at school echo the survey results obtained by D. Bubelienè (2010) concerning these factors.

In parallel to our findings emphasising unfavourable conditions of work for teachers at school and negative attitude of pupils towards physical education, results of research carried out by foreign scientists, such as J. Mintz (2007), K. Hardman (2008), K. W. Clausen, D. R. Petruka (2009), M. Brudnik (2009), show that exactly these factors cause the biggest dissatisfaction for physical education specialists in their work.

Analysing correlations between workrelated stressors and socio-demographic variables we found out that younger pedagogues experienced higher stress caused by reforms of the educational system and high numbers of pupils in a sport hall during lessons in comparison to their senior colleagues; while senior teachers of physical education emphasised responsibility as a higher work-related stress. Similarly, the data of other research works, conducted by C. L. Tonder, C. Williams (2009), J. Mukundan, K. Khandehroo (2010), show that younger specialists of physical education undergo more stress at work than their senior colleagues.

\section{CONCLUSIONS AND PERSPECTIVES}

1. These sources of stress as indicated by physical education teachers are the following: abundance of various documents and other "papers", reforms of the educational system and high responsibility for others. Such stressors as unfavourable conditions for work at school, work with groups of pupils of different genders, psychological climate at school, problems with pupils' parents do not cause much stress to specialists of physical education.

2. Younger (at the age under 35) and less experienced teachers (working for less than 10 years) experience more stress because of high numbers of pupils during lessons than their older and more experiences colleagues. Senior teachers 
of physical education (at the age over 35) and those working for a longer time (more than 10 years) emphasise the following more intensive work-related stressors: high responsibility for others, abundance of various documents and other "papers", underestimation of physical education teacher's work.

3. Low salary causes more stress to male teachers than the female ones. Female teachers feel tension at work because of other teachers' negative attitude towards physical education.

4. Teachers working in a city or town assess pupils' disrespect and high numbers of pupils in forms as a bigger stressor than teachers working in districts.

5. Physical education teachers working in gymnasiums assess personnel competition at school as a higher stressor than teachers working in the main or secondary schools.

\section{REFERENCES}

Bagdonas, A. (2004). Mokyklos stresas ir mokyklos baime: mokytojų nuomoniu tyrimas. Švietimo reforma ir mokytoju rengimas: aktualijos ir perspektyvos. Konferencijos pranešimo medžiaga. Vilnius: VPU.

Brudnik, M. (2009). Percepcion of self-efficacy and professional burnout in general education teachers. Human movement, 10 (2), 170-175.

Bubeliené, D. (2007). Mokytojų darbinis stresas: konceptualizacija ir empirinès studijos. Jaunuju mokslininku darbai, 1 (12), 56-60.

Bubelienè, D. (2010). Mokytoju profesinis stresas ir jo redukavimo prielaidos švietimo vadybos bei edukacinemis priemonemis: daktaro disertacija. Šiauliai: ŠU.

Bulotaite, L., Lepeškienè, V. (2006). Mokytojų stresas ir jo įveikos strategijos. Pedagogika, 84, 48-52.

Chaplain, R. P. (2008). Stress and psychological distress among trainee secondary teachers in England. Educational Psychology, 28 (2), 195-209.

Chimiel, N., (2005). Darbo ir organizacijos psichologija. Kaunas: Poligrafija ir informatika.

Clausen, K. W., Petruka, D. R. (2009). Tending the garden: Case studies in school stress. Arts Education Policy Review, 82 (4), 187-192.

Dirgèlienè, I., Večkienė, P. (2009). Streso rizika ir paramos lūkesčiai: socialinių darbuotojų profesinès patirties analizè. Tiltai, 1, 143-162.

Fejgin, N., Ephraty, N., Sira, D. B. (1995). Work environment and burnout of physical education teachers. Journal of Teaching in Physical Education, 15 (1), 64-78.

Hammer, T. H., Saksvik, P. O., Nytro, K., Torvan, H., Bayazit, M. (2004). Expanding the psychosocial work environment: Workplace norms and work-family conflict as correlates of stress and health. Journal of Occupational Health Psychology, 9 (1), 83-97.
Hardman, K. (2008). Physical education in schools: A global perspective. Kinesiology, 40 (1), 5-28.

Kardelienè, L. (2008). Kūno kultūros ir kitų specialybių mokytoju socialinio bendravimo nuostatos. Ugdymas. Küno kultūra. Sportas, 4 (71), 43-48.

Krawanski, A. (2009). Pedagogical challenges of physical education. Studies in Physical Culture and Tourism, 16 (4), 401-412.

Maslach, C., Schaufeli, W. B., Leiter, M. P. (2001). Job burnout. Annual Review of Psychology, 52, 397-422.

Mintz, J. (2007). Psychodynamic perspectives on teacher stress. Psychodynamic Practice, 13 (2), 153166.

Mukundan, J., Khandehroo, K. (2010). Burnout among english language teachers in Malaysia. Contemporary Issues In Education Research, 3 (1).

Ozan, B. M. (2009). A study on primary school teacher burnout levels: The northern Cyprus case. Education, 129 (4), 692-703.

Panczyk, W. (2005). School physical education and the perspectives of physical activity in the consumer society. In J. Kosiewicz (Ed.), Sport, Culture and Society (pp. 371-379). Warsaw: Akademia Wychowania Fizycznego.

Psichologijos žodynas. (1993). Sud. R. Augis, R. Kočiūnas. Vilnius: Mokslo ir enciklopedijų leidykla.

Silverman, S., Subramaniam, P. R. (1999). Student attitude toward physical education and physical activity: A review of measurement issues and outcomes. Journal of Teaching in Physical Education, 19, 97-125.

Tonder, C. L., Williams, C. (2009). Exploring the origins of burnout among secondary educators. Journal of Industrial Psychology, 35 (1), 204-218.

Мерзлякова, Д. Р. (2009). Синдром профессионального «выгорания» и метаиндивидуальность педагога. Психологическая наука и образование, 1, 55-61. 


\title{
KŪNO KULTŪROS MOKYTOJŲ DARBE PATIRIAMŲ STRESORIU YPATUMAI
}

\author{
Andrius Stočkus, Eugenija Adaškevičienè \\ Klaipédos universitetas, Klaipéda, Lietuva
}

\begin{abstract}
SANTRAUKA
Tyrimo pagrindimas ir hipotezé. Tyrimu siekta identifikuoti pagrindinius stresorius kūno kultūros mokytojų pedagoginėje veikloje ir išsiaiškinti, kurie iš jų pedagogų suvokiami kaip svarbiausi kasdieniame darbe su mokiniais.

Tikslas - nustatyti kūno kultūros mokytojų darbinius stresorius ir jų sąsajas su sociodemografiniais kintamaisiais.

Metodai. Buvo tiriama 118 kūno kultūros mokytojų, dirbančių bendrojo lavinimo mokyklose. Duomenys rinkti naudojant darbinių stresorių ir sociodemografinį klausimynus. Jie apdoroti taikant parametrinę statistiką ir naudojant Mann-Whitney (U) kriteriju.

Rezultatai. Kūno kultūros mokytojai svarbiausiais streso šaltiniais savo darbe ịvardija ịvairių dokumentų ir kitokių raštu gausą, švietimo sistemos reformas bei didelę atsakomybę už moksleivius. Netinkamos darbo sąlygos, psichologinis klimatas mokykloje, darbas su skirtingos lyties moksleiviu grupèmis, problemos su jų tèvais kūno kultūros mokytojams beveik nekelia streso.

Aptarimas ir išvados. Jaunesniems ir mažesni pedagoginio darbo stažą turintiems mokytojams didelis moksleivių skaičius sporto salëje kelia didesnį stresą nei vyresniems ir ilgiau dirbantiems kolegoms. Vyresni ir ilgiau dirbantys kūno kultūros mokytojai pažymėjo, kad jiems stipresnis darbinis stresorius yra didžiulè atsakomybe už kitus, ivvairių dokumentų ir kitokių raštų gausa, kūno kultūros mokytojo darbo nevertinimas. Vyrai yra nepatenkinti mažais atlyginimais, o moterys nurodo, kad kitų dalykų mokytojų požiūris ì kūno kultūrą kelia nepasitenkinimą darbu. Mokytojams vyrams mažas atlyginimas, o mokytojoms moterims kitų pedagogų požiūris i̇ kūno kultūrą sukelia stresą. Mieste dirbantys kūno kultūros mokytojai moksleivių nepagarbą ir didelị jų skaičių klasèse vertino kaip didesni stresorių nei dirbantys rajonuose. Gimnazijų kūno kultūros mokytojai konkurenciją mokymo įstaigoje vertina kaip stipresnị stresorių nei pedagogai, dirbantys pagrindinėse ar vidurinėse mokyklose.
\end{abstract}

Raktažodžiai: kūno kultūra, mokytojų stresas, nuovargis.

Gauta 2013 m. birželio 19 d.

Received on 19 June, 2013 